\title{
Analisis Capaian Pembangunan SDM dan Faktor-faktor Pendorong Penyerapan Tenaga Kerja di Provinsi Bali
}

\author{
Theresia Mutiara Galistya \\ Fungsional Statistisi Muda BPS Provinsi Bali \\ email: theresia.mutiara@bps.go.id
}

\begin{abstract}
Human resource development in the Bali Province can be illustrated through the development of the Human Development Index (HDI) achievements and employment conditions. Until 2018, HDI of Bali Province recorded continued to grow and is at a "high" level. The challenge that arises is that there are still gaps in the achievement of HDI at the regency level. Efforts to increase the Mean Years of Schooling (RLS) and per capita expenditure in regency with a "moderate" HDI status seem to be one solution to narrowing disparities in human resource development between regions. In view of employment conditions, Bali's Open Unemployment Rate (TPT) was recorded to be the lowest nationally. However, the low level of education possessed by most workers has an impact on the low wages or salaries that can be obtained. The study was complemented by causal analysis to see the effect of economic growth, investment, and the Provincial Minimum Wage (UMP) on employment in the Bali Province. Case studies are conducted according to data conditions that released by Statistics Indonesia for 2009-2017. The results showed that simultaneously all three variables had a close relationship with employment. This is indicated by the R2 value that recorded at 94,3 percent. Partially, economic growth has a positive effect on employment though not significant. Investment and UMP variables have a positive and significant effect on employment in the Bali Province.
\end{abstract}

Keywords: economic growth, human resource, investment, labor absorption.

\section{PENDAHULUAN}

Salah satu prioritas program kerja pemerintahan Presiden Joko Widodo dan Wakil Presiden Ma'ruf Amin adalah pembangunan sumber daya manusia (SDM) yang unggul, produktif, dan mampu bersaing di kancah global. Berdasarkan hasil Global Competitiveness Index (GTCI) tahun 2019, yakni pemeringkatan daya saing negara berdasarkan kemampuan atau talenta SDM yang dimiliki, menempatkan Indonesia pada posisi keenam di ASEAN dan posisi ke-67 dari total 125 negara. Indonesia tercatat meraih skor 38,61, cukup jauh dibandingkan Singapura yang menyandang peringkat pertama di antara negara-negara anggota ASEAN dengan capaian skor 77,27 . Salah satu aspek yang dinilai berpengaruh besar adalah masih cukup rendahnya tingkat pendidikan di Indonesia. Menilik rata-rata lama sekolah (RLS), jika rata-rata penduduk di Singapura menempuh pendidikan selama 11,5 tahun, di Indonesia masih berada pada kisaran 8 tahun atau hingga setingkat sekolah lanjutan tingkat pertama (SMP).

Masih rendahnya tingkat daya saing SDM Indonesia menjadi tantangan besar saat perkembangan teknologi digadang-gadang memasuki era Teknologi Industri 4.0. Peningkatan level industri ke Industri 4.0 atau sektor industri teknologi digital tentunya akan memberi pengaruh pada pasar penawaran dan permintaan tenaga kerja. Dilihat dari sisi permintaan (demand), terlihat adanya pergeseran arus investasi dari padat 
karya ke padat modal dan teknologi. Hal ini mendorong serapan tenaga kerja semakin terbatas. Kondisi ini tercermin dari data Badan Koordinasi Penanaman Modal (BKPM) yang mencatat bahwa pada triwulan III-2019, secara y-on-y, jumlah investasi meningkat tetapi jumlah tenaga kerja yang terserap justru menurun. Bahkan jika mencermati series yang lebih panjang, pada tahun 2010 setiap Rp 1 triliun investasi mampu menyerap sekitar 5.014 tenaga kerja. Namun, pada tahun 2018, rasio berubah menjadi sekitar 1.650 orang per Rp 1 triliun investasi. Memandang dari sisi penawaran (supply), peliknya problematika ketenagakerjaan seakan dibebani lagi dengan rendahnya kompetensi atau kualitas tenaga kerja yang secara rata-rata tamat SMP atau bahkan hanya setingkat sekolah dasar (SD) ke bawah. Meskipun setiap tahun terlihat adanya catatan peningkatan jenjang pendidikan yang ditempuh, kecepatannya dirasa masih belum mampu memenuhi tuntutan laju perkembangan dunia kerja dewasa ini. Untuk mengejar ketertinggalan dan menciptakan SDM unggul demi mewujudkan Indonesia Maju, gebrakan besar di bidang pendidikan nampaknya menjadi suatu keharusan. Terlebih pemerintah Indonesia tengah bertekad mencetak Generasi Emas pada tahun 2045.

Lantas bagaimana dengan Provinsi Bali yang merupakan salah satu provinsi dengan kekhasan adat istiadat dan budaya di Indonesia? Program kerja pemerintah pusat tentunya sejalan dengan visi Gubernur Wayan Koster dan Wakil Gubernur Tjokorda Oka Artha Ardhana Sukawati, yakni "Nangun Sat Kerthi Loka Bali". Melalui Pola Pembangunan Nasional Semesta Berencana, pemerintah Provinsi Bali berupaya menuju Bali Era Baru dengan mewujudkan Krama Bali yang sejahtera, bahagia sekala dan niskala. Salah satu upaya nyata yang ditempuh dengan menggenjot penyelenggaraan ketenagakerjaan yang mencakup pembangunan SDM, peningkatan produktivitas, daya saing tenaga kerja, pengupahan, dan pembinaan hubungan industrial.

Sejatinya, Pemerintah Provinsi Bali telah tanggap menyadari bahwa pembangunan SDM merupakan prioritas utama untuk merespons fenomena bonus demografi yang menciptakan peluang tersendiri. Bonus demografi (demographic dividend) dianggap sebagai windows of opportunity karena beban penduduk usia produktif untuk menanggung penduduk usia non produktif berada di bawah 50 persen. Provinsi Bali diperkirakan telah mengalami bonus demografi sejak tahun 1995 dengan angka rasio beban ketergantungan tercatat sebesar 47,09 persen dan diproyeksikan masih akan mengalami hingga tahun 2020 dengan rasio sekitar 43,36 persen (BPS, 2015). Kondisi ini tentu berkonsekuensi terhadap penyediaan lapangan pekerjaan karena adanya ledakan penduduk usia kerja. Pertambahan angkatan kerja yang tidak diimbangi dengan perluasan penyerapan tenaga kerja akan berdampak pada peningkatan angka pengangguran.

Untuk mencermati sejauhmana capaian pembangunan SDM dan mengetahui faktor-faktor yang diduga berpengaruh terhadap penyerapan tenaga kerja di Provinsi Bali, dilakukan penelitian menggunakan analisis deskriptif dan analisis inferensia. Kerangka berpikir yang digunakan dalam analisis ini adalah menemukan hubungan (kausal) antara variabel pertumbuhan ekonomi, investasi, dan Upah Minimum Provinsi (UMP) terhadap penyerapan tenaga kerja. Merajut pertumbuhan ekonomi diduga akan berdampak pada penciptaan lapangan pekerjaan. Laju pertumbuhan ekonomi yang lebih tinggi dari tingkat pertumbuhan penduduk dapat mendorong perluasan kegiatan 
perekonomian yang pada gilirannya mampu menekan angka pengangguran. Kondisi ideal adalah saat pertumbuhan ekonomi mendorong peningkatan penyerapan tenaga kerja. Selain pertumbuhan ekonomi, secara teoritis masalah ketersediaan lapangan pekerjaan atau kesempatan kerja dapat pula diatasi dengan memaksimalkan investasi yang produktif di berbagai sektor ekonomi. Investasi yang lazim pula disebut sebagai penanaman modal atau pembentukan modal dapat menjadi salah satu faktor krusial bagi kelangsungan pembangunan ekonomi. Faktor lain yang dirasa tidak kalah penting adalah upah yang diberikan kepada tenaga kerja. Upah berperan dalam mempengaruhi permintaan dan penawaran tenaga kerja yang terserap dalam setiap kegiatan produksi (Wijaya A., dkk, 2014).

\section{PEMBAHASAN}

\section{Capaian Pembangunan Manusia di Provinsi Bali}

Pembangunan manusia yang diukur melalui capaian kualitas kesehatan, pendidikan, dan pemenuhan kebutuhan hidup masyarakat di Provinsi Bali tercatat mengalami peningkatan setiap tahunnya. Hal ini tercermin dari perkembangan Indeks Pembangunan

Manusia

selama periode tahun 2010 hingga tahun 2018 yang secara rata-rata tercatat tumbuh sebesar 0,81 persen per tahun dan selalu berada pada level "tinggi".

$\begin{array}{lrr} & \text { Pada } & \text { tahun } \\ \text { 2018, } & \text { IPM } & \text { Bali } \\ \text { tercatat } & \text { mencapai }\end{array}$

74,77. Angka ini meningkat sebesar 0,47 poin atau tumbuh 0,63 persen dibandingkan tahun sebelumnya. Capaian

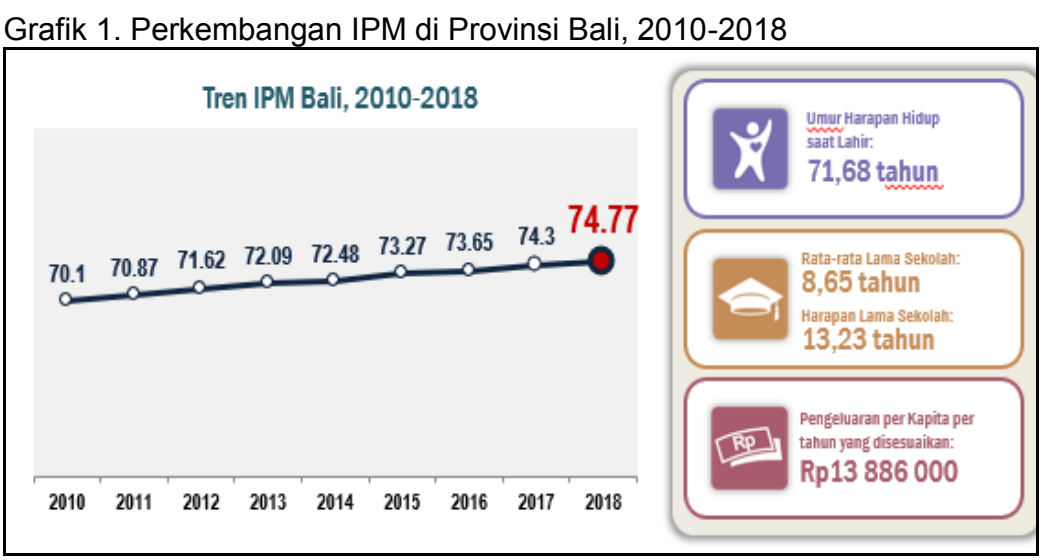

Sumber: BPS Provinsi Bali

Grafik 2. Perkembangan Komponen Pembentuk IPM di Provinsi Bali, 2010-2018

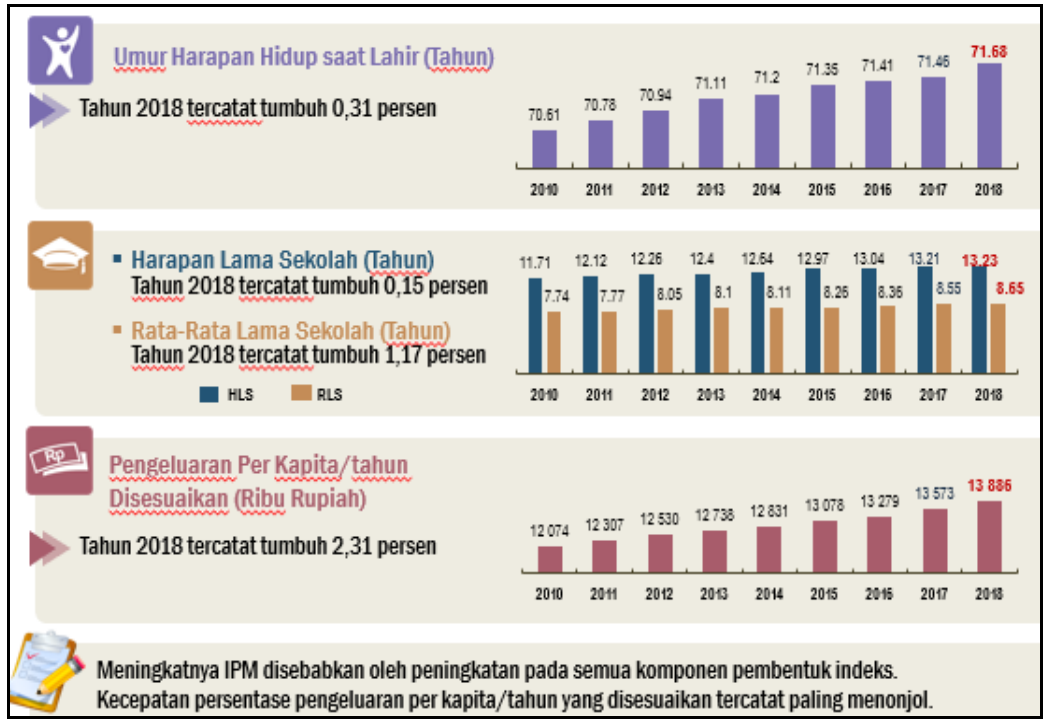

Sumber: BPS Provinsi Bali

\section{IPM Bali tersebut}

merupakan tertinggi kelima secara nasional, di bawah DKI Jakarta, DI Yogyakarta, Kalimantan Timur, dan Kepulauan Riau. 
Dilihat dari komponen-komponen pembentuk IPM, tercatat perkembangan ketiga aspek esensial, yakni umur panjang dan hidup sehat, pengetahuan, dan standar hidup layak mendorong peningkatan capaian IPM Bali. Dimensi umur panjang dan hidup sehat yang direpresentasikan melalui Umur Harapan Hidup saat Lahir (UHH) tercatat tumbuh 1,07 tahun selama periode tahun 2010-2018. Pada tahun 2018, UHH tercatat sebesar 71,68 tahun, artinya bayi yang lahir pada tahun 2018 memiliki harapan untuk hidup hingga usia 71,68 tahun atau lebih lama 0,22 tahun dibanding tahun 2017.

Untuk dimensi pengetahuan yang diukur melalui dua indikator, yakni Harapan Lama Sekolah (HLS) dan Rata-rata Lama Sekolah (RLS) juga tercatat terus mengalami pertumbuhan. Selama periode tahun 2010-2018, HLS tercatat meningkat sebesar 1,52 tahun dan RLS tercatat meningkat sebesar 0,91 tahun. Peningkatan HLS dan RLS menjadi sinyalemen positif bahwa semakin banyak penduduk yang bersekolah hingga tingkat yang lebih tinggi. Pada tahun 2018, HLS di Provinsi Bali tercatat mencapai 13,23 tahun. Artinya, anak-anak usia 7 tahun memiliki peluang untuk menempuh pendidikan hingga lulus Diploma I (DI) atau perguruan tinggi semester dua. Melalui capaian RLS pada tahun 2018, dapat ditunjukkan bahwa secara rata-rata penduduk Provinsi Bali usia 25 tahun ke atas telah mengenyam pendidikan formal selama 8,65 tahun atau telah menyelesaikan pendidikan hingga kelas VIII (SMP tingkat II).

Demikian halnya dengan dimensi standar hidup layak yang digambarkan melalui indikator pengeluaran per kapita (harga konstan 2012). Pada tahun 2018, pengeluaran per kapita penduduk di Provinsi Bali tercatat sebesar Rp 13,89 juta per tahun. Selama periode delapan tahun terakhir, pengeluaran per kapita

Grafik 3. Pengelompokan Capaian IPM Kabupaten/Kota di Provinsi Bali, 2018

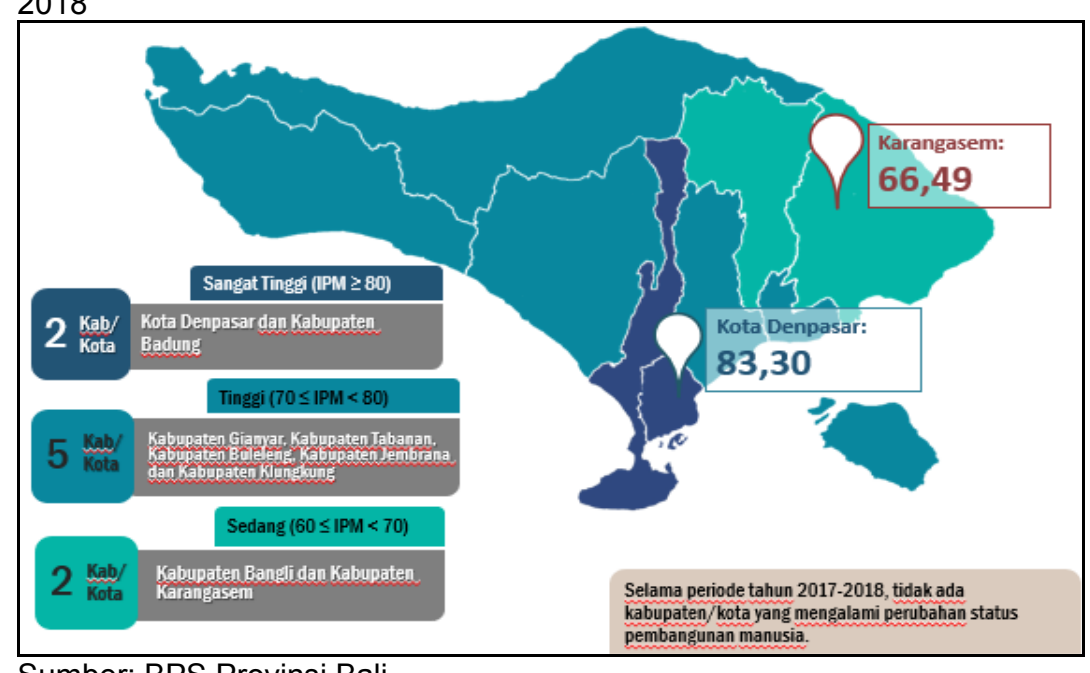

Sumber: BPS Provinsi Bali penduduk tercatat rata-rata meningkat sebesar 1,76 persen per tahun.

Meski capaian IPM Bali selalu berada pada level "tinggi", bukan berarti tidak menyisakan

sejumlah tantangan. Satu diantaranya adalah masih adanya kesenjangan pencapaian pembangunan manusia di tingkat kabupaten/kota. Tercatat pada tahun 2018, capaian IPM tertinggi diraih oleh Kota Denpasar $(83,30)$ dan terendah di Kabupaten Karangasem $(66,49)$. Dari komponen pembentuk IPM, jauhnya gap utamanya didorong oleh masih rendahnya RLS dan pengeluaran per kapita penduduk di Kabupaten Karangasem. RLS Kabupaten Karangasem tercatat 5,97 tahun. Cukup jauh dibandingkan RLS Kota Denpasar yang tercatat mencapai 11,16 tahun. Pada komponen pengeluaran per kapita, tercatat di 
Kabupaten Karangasem sebesar Rp 10,05 juta per tahun, sedangkan di Kota Denpasar telah mencapai Rp 19,70 juta per tahun.

\section{Kondisi Ketenagakerjaan di Provinsi Bali}

Kualitas SDM
selain ditampilkan
dalam capaian IPM,
dapat pula ditinjau
dari sudut pandang
ketenagakerjaan.
Berdasarkan hasil
Survei Angkatan Kerja
Nasional (Sakernas),
perkembangan
kondisi di
ketenagakerjaan di
Provinsi Bali selama
periode tahun 2017-
2019 dapat dikatakan
cukup baik, meski
sedikit berfluktuasi.

Grafik 4. Persentase Pekerja Formal dan Informal di Provinsi Bali, 20172019

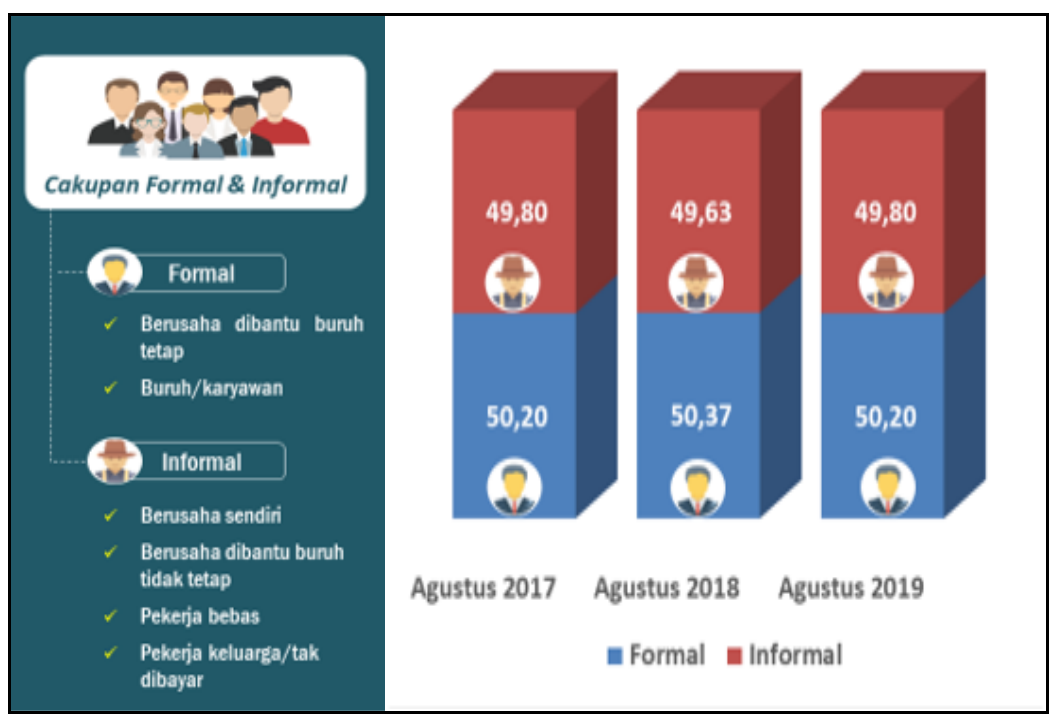

Sumber: BPS Provinsi Bali

Tabel 1. Ringkasan Indikator Ketenagakerjaan di Provinsi Bali, 2017-2019

\begin{tabular}{|c|c|c|c|}
\hline Uraian & 2017 & 2018 & 2019 \\
\hline (1) & (2) & (3) & (4) \\
\hline 1. Penduduk Usia Kerja & 3.235 .563 & 3.288 .908 & 3.338 .767 \\
\hline 2. Angkatan Kerja : & 2.434 .450 & 2.525 .355 & 2.466 .230 \\
\hline a. Bekerja & 2.398 .307 & 2.490 .870 & 2.428 .679 \\
\hline b. Pengangguran & 36.143 & 34.485 & 37.551 \\
\hline 3. Bukan Angkatan Kerja & 801.113 & 763.553 & 872.537 \\
\hline 4. Tingkat Partisipasi Angkatan Kerja/TPAK (\%) & 75,24 & 76,78 & 73,87 \\
\hline 5. Tingkat Pengangguran Terbuka/TPT (\%) & 1,48 & 1,37 & 1,52 \\
\hline 6. Pekerja Tidak Penuh Waktu (<35 Jam) & 550.541 & 583.676 & 605.581 \\
\hline \multicolumn{4}{|l|}{ 7. Pekerja Formal } \\
\hline a. Buruh/Karyawan/Pegawai & 1.103 .525 & 1.144 .726 & 1.128 .042 \\
\hline b. Berusaha Dibantu Buruh Tetap/Buruh Dibayar & 100.341 & 109.851 & 91.255 \\
\hline Total Pekerja Formal & 1.203 .866 & 1.254 .577 & 1.219.297 \\
\hline \multicolumn{4}{|l|}{ 8. Pekerja Informal } \\
\hline a. Berusaha Sendiri & 353.830 & 349.431 & 402.677 \\
\hline b. Berusaha Dibantu Buruh Tidak Tetap/Tidak Dibayar & 371.848 & 406.506 & 366.243 \\
\hline c. Pekerja Bebas & 167.900 & 186.976 & 170.428 \\
\hline d. Pekerja Tak Dibayar & 300.863 & 293.380 & 270.034 \\
\hline Total Pekerja Informal & 1.194 .441 & 1.236 .293 & 1.209 .382 \\
\hline
\end{tabular}

Sumber: BPS Provinsi Bali

Terutama bila dilihat dari indikator Tingkat Pengangguran Terbuka (TPT) yang tercatat merupakan persentase terendah secara nasional, bahkan sejak tahun 2010. Demikian halnya bila dilihat dari proporsi pekerja formal dan informal. Selama periode tahun 2017-2019, tercatat persentase pekerja formal masih selalu lebih tinggi dibandingkan pekerja informal. Meski, secara matematis tidak terlalu jauh berbeda. Perbandingan persentase pekerja formal dan pekerja informal selama periode tahun 2017-2019, 
berturut-turut tercatat sebagai berikut 50,20 persen banding 49,80 persen, 50,37 persen banding 49,63 persen, dan 50,20 persen banding 49,80 persen.

Menilik dari sudut pandang lapangan usaha yang digeluti oleh penduduk di Provinsi Bali, terlihat bahwa struktur lapangan pekerjaan utama masih didominasi oleh Kategori G (Perdagangan Besar dan Eceran; Reparasi Mobil dan Sepeda Motor), Kategori A (Pertanian, Kehutanan, dan Perikanan), Kategori C (Industri Pengolahan), dan Kategori I (Penyediaan Akomodasi dan Makan Minum). Kondisi ini sesuai dengan Bali yang identik dengan sektor pariwisata dan merupakan daerah agraris. Namun, kekhasan yang dimiliki oleh Provinsi Bali dengan pariwisatanya seakan mendorong transformasi dari sektor primer ke sektor tersier lebih cepat dibanding provinsi lainnya di Indonesia. Lapangan pekerjaan dengan trend meningkat didominasi oleh sektor yang terkoneksi langsung dengan pariwisata dan sektor penunjangnya, seperti Kategori I (Penyediaan Grafik 5. Jumlah Penduduk Usia 15 Tahun ke Atas di Provinsi Bali yang Bekerja Menurut Lapangan Usaha, 2017-2019

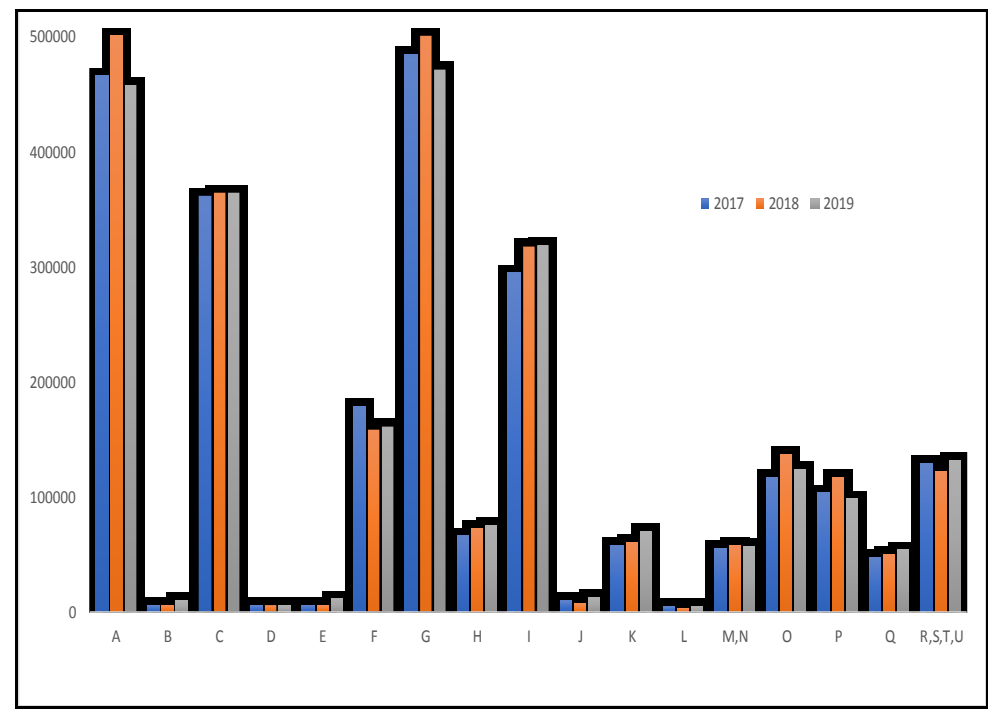

Sumber: BPS Provinsi Bali

\begin{tabular}{|c|c|c|c|}
\hline Kategori & $\begin{array}{l}\text { Nama Lapangan } \\
\text { Usaha }\end{array}$ & Kategori & $\begin{array}{l}\text { Nama Lapangan } \\
\text { Usaha }\end{array}$ \\
\hline A & $\begin{array}{l}\text { Pertanian, Kehutanan, } \\
\text { dan Perikanan }\end{array}$ & $\mathrm{J}$ & $\begin{array}{l}\text { Informasi dan } \\
\text { Komunikasi }\end{array}$ \\
\hline B & $\begin{array}{l}\text { Pertambangan dan } \\
\text { Penggalian }\end{array}$ & $\mathrm{K}$ & $\begin{array}{l}\text { Jasa Keuangan } \\
\text { dan Asuransi }\end{array}$ \\
\hline $\mathrm{C}$ & Industri Pengolahan & $\mathrm{L}$ & Real Estat \\
\hline $\mathrm{D}$ & $\begin{array}{l}\text { Pengadaan Listrik dan } \\
\text { Gas }\end{array}$ & $\mathrm{M}, \mathrm{N}$ & Jasa Perusahaan \\
\hline $\mathrm{E}$ & $\begin{array}{l}\text { Pengadaan } \\
\text { Air,Pengelolaan } \\
\text { Sampah, Limbah dan } \\
\text { Daur Ulang }\end{array}$ & $\mathrm{O}$ & $\begin{array}{l}\text { Administrasi } \\
\text { Pemerintahan, } \\
\text { Pertahanan dan } \\
\text { Jaminan Sosial } \\
\text { Wajib }\end{array}$ \\
\hline $\mathrm{F}$ & Konstruksi & $P$ & Jasa Pendidikan \\
\hline G & $\begin{array}{l}\text { Perdagangan Besar } \\
\text { dan Eceran; Reparasi } \\
\text { Mobil dan Sepeda } \\
\text { Motor }\end{array}$ & Q & $\begin{array}{l}\text { Jasa Kesehatan } \\
\text { dan Kegiatan } \\
\text { Sosial }\end{array}$ \\
\hline $\mathrm{H}$ & $\begin{array}{l}\text { Transportasi dan } \\
\text { Pergudangan }\end{array}$ & $\begin{array}{l}\mathrm{R}, \mathrm{S}, \mathrm{T} \\
\mathrm{U}\end{array}$ & Jasa lainnya \\
\hline I & $\begin{array}{l}\text { Penyediaan } \\
\text { Akomodasi dan Makan } \\
\text { Minum }\end{array}$ & & \\
\hline
\end{tabular}

Akomodasi dan Makan Minum), Kategori H (Transportasi dan Pergudangan), dan Kategori R, S, T, U (Jasa Lainnya). Meski demikian, lapangan pekerjaan di Kategori C (Industri Pengolahan) nampaknya masih cukup menjanjikan sebagai sektor unggulan dilihat dari terus tumbuhnya penyerapan tenaga kerja pada sektor tersebut.

Kualitas ketenagakerjaan selain dilihat dari capaian Tingkat Partisipasi Angkatan Kerja (TPAK) dan Tingkat Pengangguran Terbuka (TPT), terlihat pula dari 
kompetensi pendidikan yang dimiliki oleh tenaga kerja. Meski tercatat memiliki TPT rendah, sebagian besar tenaga kerja di Bali berpendidikan SD ke bawah. Begitu pula dengan tamatan SMK yang diharapkan siap untuk memasuki dunia kerja dengan bekal keterampilan yang diajarkan selama sekolah, tercatat masih cukup rendah. Rendahnya pendidikan yang dienyam tentunya akan berdampak pada kualitas pekerjaan yang mampu dimasuki dan penghasilan yang mampu didapat.

Untuk melihat

perbandingan antara

penghasilan tenaga

kerja dengan lapangan

pekerjaan yang digeluti,

sebagai contoh

disandingkan data

terkait rata-rata

upah/gaji bersih

sebulan dari

buruh/karyawan

dengan jumlah tenaga

kerja di masing-masing

lapangan usaha. Dari komposisinya, dapat diketahui bahwa

Grafik 6. Penduduk Provinsi Bali yang Bekerja Menurut

Pendidikan Tertinggi yang Ditamatkan, 2017-2019

sebagian besar tenaga kerja di Provinsi Bali terserap pada lapangan pekerjaan yang secara rata-rata memberikan upah/gaji lebih rendah dibanding lapangan usaha sektor jasa-jasa yang menyerap lebih sedikit tenaga kerja. Fenomena ini nampaknya berkorelasi dengan kualitas pendidikan tenaga kerja di Provinsi Bali yang masih rendah. Pada

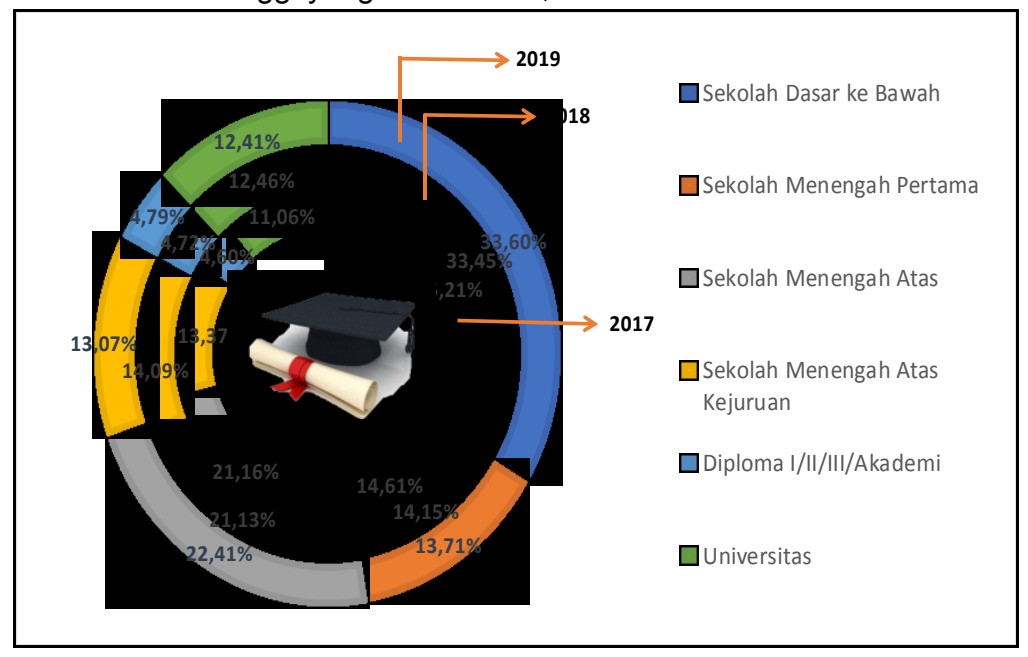

Sumber: BPS Provinsi Bali

Grafik 7. Rata-rata Upah/Gaji Bersih Sebulan (rupiah) Buruh/Karyawan dan Jumlah Penduduk Penduduk di Provinsi Bali yang Bekerja Menurut Lapangan Usaha, 2019

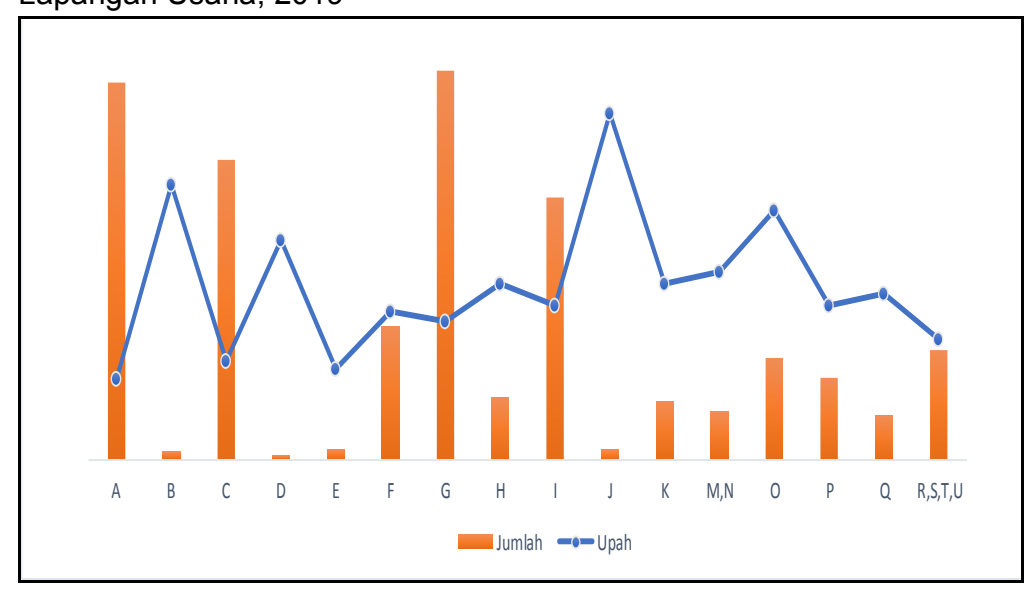

Sumber: BPS Provinsi Bali

gilirannya, baru sebagian kecil tenaga kerja yang mampu terserap oleh bidang-bidang pekerjaan dengan upah/gaji lebih besar. Tentunya dengan persyaratan kompetensi pendidikan dan keterampilan yang lebih tinggi dan lebih kompetitif.

ANALISIS PENGARUH PERTUMBUHAN EKONOMI, INVESTASI, DAN UPAH MINIMUM PROVINSI TERHADAP PENYERAPAN TENAGA KERJA DI PROVINSI BALI, STUDI KASUS: TAHUN 2009-2017

\section{Analisis Deskriptif Masing-masing Variabel}




\section{a. Penyerapan Tenaga Kerja}

Penyerapan tenaga kerja dalam penelitian ini menggunakan pendekatan jumlah penduduk bekerja yang dipublikasikan oleh Badan Pusat Statistik (BPS) Provinsi Bali dan merupakan hasil dari Sakernas. BPS mengkategorikan penduduk bekerja sebagai penduduk usia kerja (15-64 tahun) yang termasuk dalam angkatan kerja dan sedang bekerja. Selama periode tahun 2009-2017, jumlah penduduk bekerja yang mampu terserap dalam berbagai lapangan pekerjaan menunjukkan peningkatan. Tercatat pada tahun 2009 terdapat 2.057.118 orang yang bekerja dan meningkat menjadi 2.398.307 orang pada tahun 2017.

Salah satu indikator capaian pembangunan ekonomi di suatu wilayah adalah besaran Produk Domestik Regional Bruto (PDRB). PDRB merupakan jumlah nilai tambah atas barang dan jasa yang dihasilkan oleh berbagai unit produksi di suatu wilayah dalam jangka waktu tertentu (biasanya satu tahun). Pertumbuhan ekonomi dihitung dari perubahan PDRB atas dasar harga konstan (ADHK) pada suatu periode dibandingkan periode sebelumnya. Secara teori, pertumbuhan ekonomi berkorelasi positif terhadap penyerapan tenaga kerja.

Grafik 8. Jumlah Penduduk Bekerja (orang) di Provinsi Bali, 2009-2017

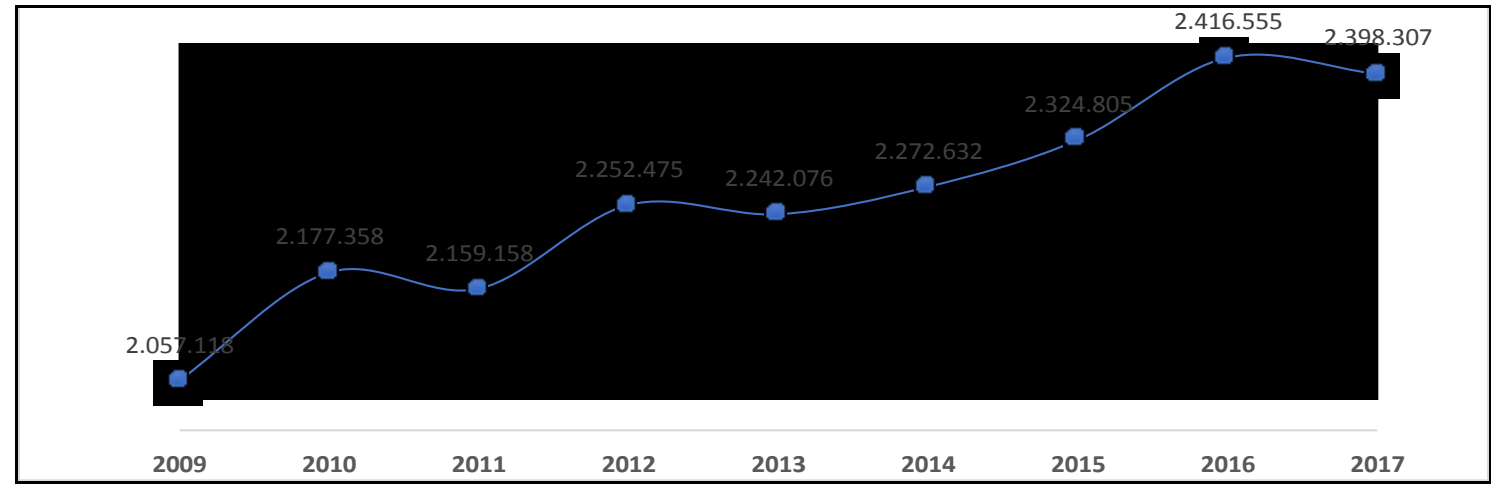

Sumber: BPS Provinsi Bali

\section{b. Pertumbuhan Ekonomi}

Salah satu indikator capaian pembangunan ekonomi di suatu wilayah adalah besaran Produk Domestik Regional Bruto (PDRB). PDRB merupakan jumlah nilai tambah atas barang dan jasa yang dihasilkan oleh berbagai unit produksi di suatu wilayah dalam jangka waktu tertentu (biasanya satu tahun). Pertumbuhan ekonomi dihitung dari perubahan PDRB atas dasar harga konstan (ADHK) pada suatu periode dibandingkan periode sebelumnya. Secara teori, pertumbuhan ekonomi berkorelasi positif terhadap penyerapan tenaga kerja. Pertumbuhan ekonomi di Provinsi Bali pada periode tahun 2009-2017 tercatat cukup berfluktuasi. Namun, tetap pada kisaran di atas 5 persen. Pertumbuhan ekonomi tertinggi yang dicatatkan pada periode tersebut adalah pada tahun $2012(6,96 \%)$ dan terendah pada tahun 2009 (5,30\%). 
Grafik 9. Pertumbuhan Ekonomi (\%) di Provinsi Bali, 2009-2017

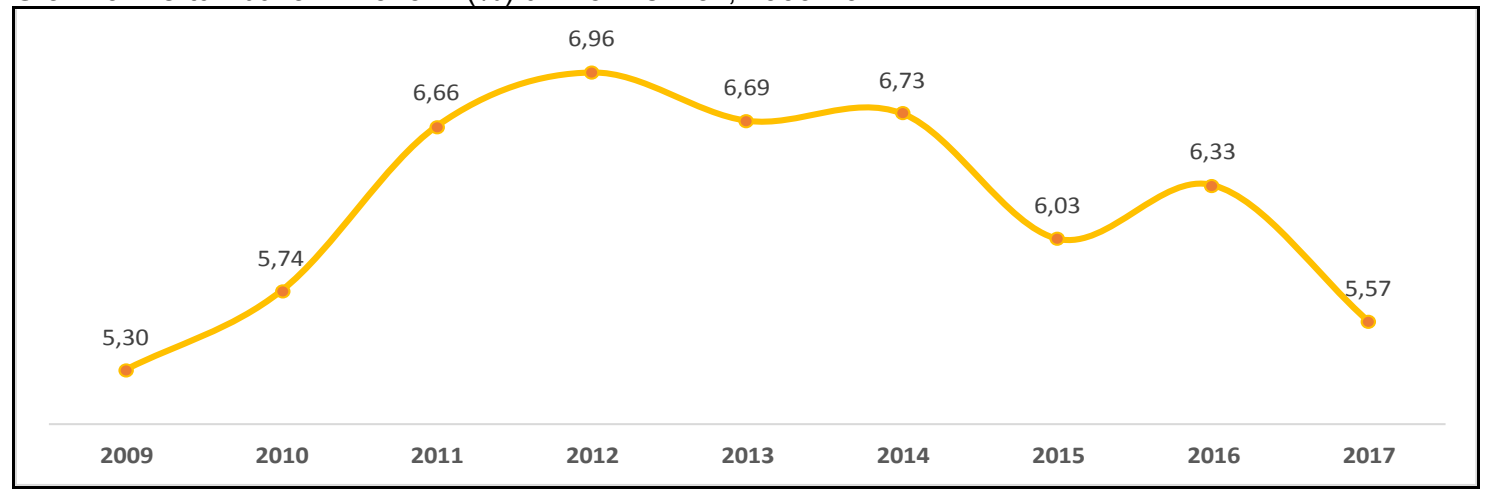

Sumber: BPS Provinsi Bali

c. Total Realisasi Investasi

Investasi dapat diartikan sebagai pengeluaran atau pembelanjaan modal dan perlengkapan produksi untuk menambah kemampuan memproduksi barang dan jasa yang tersedia dalam perekonomian (Sukirno, 2006). Berdasarkan sumbernya, investasi dapat digolongkan menjadi dua, yaitu investasi yang berasal dari dalam negeri (Penanaman Modal Dalam Negeri/PMDN) dan investasi yang berasal dari luar negeri (Penanaman Modal Asing/PMA) (Deliarnov, 2005). Sumber PMDN dapat berasal dari tabungan sukarela masyarakat, tabungan pemerintah, dan tabungan paksa, sedangkan untuk PMA dapat berupa bantuan luar negeri maupun investasi pihak asing. Selama periode tahun 2009-2017, total realisasi investasi, baik PMDN maupun PMA, di Provinsi Bali tercatat menunjukkan trend peningkatan. Hanya terlihat di tahun 2014 sempat mengalami penurunan cukup dalam sebelum kembali menunjukkan trend positif. Jika dilihat secara total realisasi dari tahun 2009-2017, investasi PMDN memiliki proporsi yang lebih besar dibanding PMA, yakni sekitar 59 persen berbanding 41 persen. Dengan total tenaga kerja Indonesia yang mampu terserap, masing-masing sekitar 123 ribu orang dari PMDN dan 63 ribu dari PMA

Grafik 10. Total Realisasi Investasi PMDN dan PMA (juta rupiah) di Provinsi Bali, 2009-2017

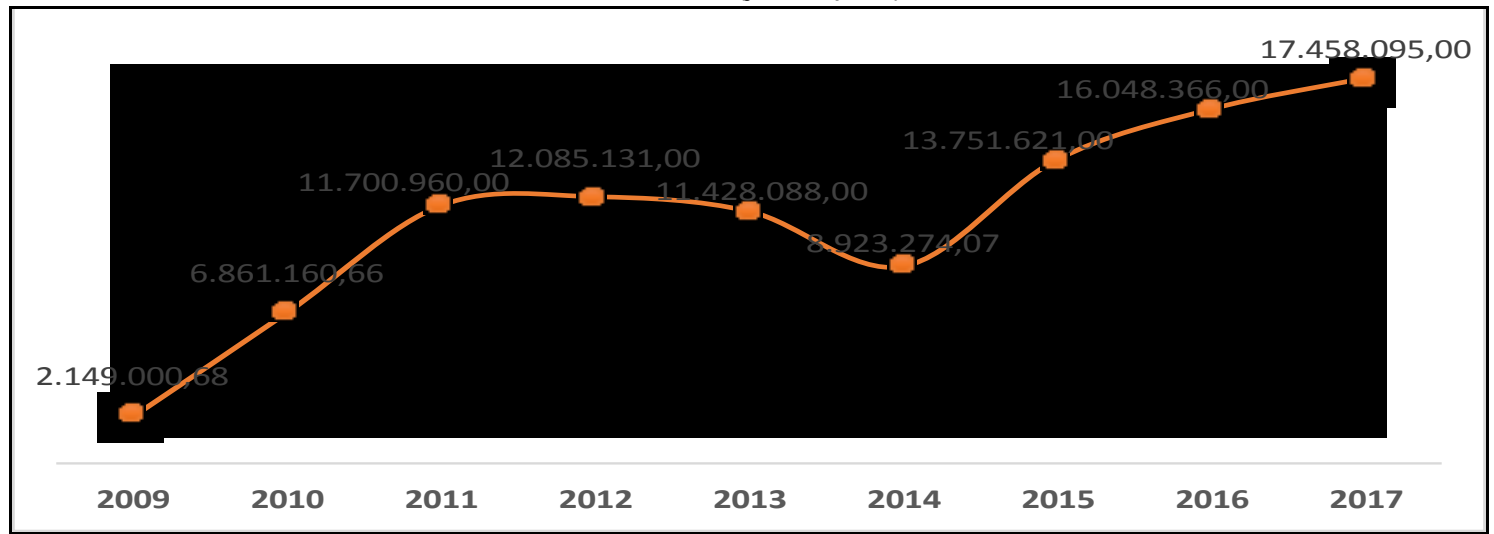

Sumber: Dinas Penanaman Modal dan Pelayanan Terpadu Satu Pintu Provinsi Bali (Bali Dalam Angka)

d. Upah Minimum Provinsi (UMP)

Upah merupakan sejumlah dana yang dikeluarkan oleh perusahaan/pengusaha untuk membayar tenaga kerja karena telah menghasilkan produk, baik barang maupun jasa (Sumarsono, 2003). Menurut Undang-undang Tenaga Kerja Nomor 13 tahun 
2000, upah dapat diartikan sebagai hak pekerja/buruh yang diterima dan dinyatakan dalam bentuk uang sebagai imbalan yang ditetapkan dan dibayarkan menurut suatu perjanjian kerja, kesepakatan, atau peraturan perundang-undangan, termasuk tunjangan bagi pekerja/buruh dan keluarganya.

Upah minimum adalah upah bulanan terendah meliputi upah/gaji pokok termasuk tunjangan yang telah ditetapkan pemerintah (Pratomo dan Saputra, 2011). Sebagaimana diatur dalam Undang-undang Nomor 13 tahun 2003, kebijakan penetapan upah minimum bertujuan untuk mencapai kebutuhan hidup layak. Selama periode tahun 2009-2017, UMP Bali terus meningkat seiring dengan naiknya upah nominal kesejahteraan (upah rill). UMP Bali pada tahun 2009 tercatat sebesar Rp 760 ribu dan mencapai Rp 1.956 ribu pada tahun 2017. Besar peningkatan yang terjadi tercatat sekitar 2,5 kali lipat. Salah satu pertimbangan penetapan UMP, yakni tingkat inflasi tahunan berada pada kisaran 5 persen secara rata-rata dalam periode tersebut.

Grafik 11. Upah Minimum Provinsi Bali, 2009-2017

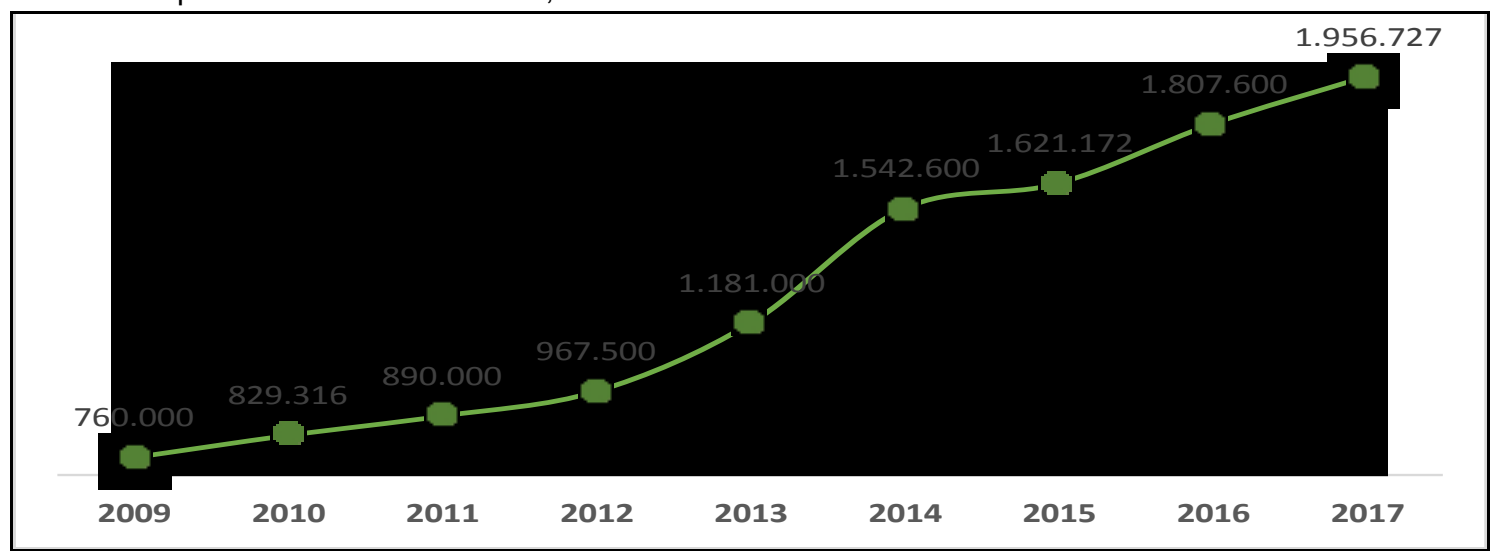

Sumber: Bali Dalam Angka

\section{ANALISIS INFERENSIA}

Sebagai gambaran untuk melihat hubungan (kausal) antara pertumbuhan ekonomi, investasi, dan Upah Minimum Provinsi (UMP) terhadap penyerapan tenaga kerja di Provinsi Bali, dilakukan penelitian dengan metode analisis regresi linier berganda melalui pendekatan Ordinary Least Square (OLS). Data yang digunakan merupakan data time series dengan studi kasus selama periode tahun 2009-2017. Bentuk persamaan regresi linier berganda yang digunakan dalam penelitian ini dirumuskan sebagai berikut:

$Y=\beta_{0}+\beta_{1} X_{1}+\beta_{2} X_{2}+\beta_{3} X_{3}+\varepsilon$

di mana:

$Y \quad=$ Jumlah tenaga kerja yang terserap (juta orang)

$\beta_{0} \quad=$ Konstanta

$\beta_{1}, \beta_{2}, \beta_{3} \quad=$ Koefisien masing-masing variabel independen

$X_{1} \quad=$ Pertumbuhan ekonomi (persen)

$X_{2} \quad=$ Total realisasi investasi (triliun rupiah)

$X_{3} \quad=$ UMP (juta rupiah). 
Berdasarkan hasil penelitian, diperoleh model persamaan regresi linier berganda yang dirumuskan sebagai berikut:

$$
\begin{aligned}
\text { Bekerja_Juta } & =1,858+0,014 \text { Pertumbuhan_Ekonomi }+0,010 \text { Inves_Triliun } \\
& +0,156 \text { UMP_Juta }+\varepsilon
\end{aligned}
$$

Kesimpulan:

1. Nilai koefisien determinasi $\left(R^{2}\right)$ bernilai 94,3 persen yang berarti secara simultan, ketiga variabel independen, yakni pertumbuhan ekonomi, investasi, UMP mampu menjelaskan variasi variabel dependen, yakni penyerapan tenaga kerja, dengan sangat baik.

2. Penyerapan tenaga kerja akan sebesar 1.858 .000 orang jika semua variabel independen bernilai konstan.

3. Hubungan antara pertumbuhan ekonomi terhadap penyerapan tenaga kerja positif, tetapi tidak signifikan. Apabila pertumbuhan ekonomi tumbuh 1 persen, maka akan terdapat penambahan tenaga kerja yang terserap sebanyak 140 orang dengan asumsi variabel independen yang lain bernilai konstan.

4. Hubungan antara investasi terhadap penyerapan tenaga kerja positif dan signifikan. Apabila total realisasi investasi meningkat 1 triliun rupiah, maka akan terdapat penambahan tenaga kerja yang terserap sebanyak 10.000 orang dengan asumsi variabel independen yang lain bernilai konstan.

5. Hubungan antara UMP terhadap penyerapan tenaga kerja positif dan signifikan. Apabila UMP meningkat 1 juta rupiah, maka akan terdapat penambahan jumlah tenaga kerja yang terserap sebanyak 156.000 orang dengan asumsi variabel independen yang lain bernilai konstan.

\begin{tabular}{|c|c|c|c|c|c|c|c|c|}
\hline \multicolumn{6}{|c|}{ Model Summary } & & & \\
\hline Model & $\mathrm{R}$ & R Square & \multicolumn{2}{|c|}{$\begin{array}{l}\text { Adjusted R } \\
\text { Square }\end{array}$} & $\begin{array}{l}\text { Std. Error of } \\
\text { the Estimate }\end{array}$ & & & \\
\hline 1 & $.971^{\mathrm{a}}$ & .943 & & .908 & .03495 & & & \\
\hline \multicolumn{9}{|c|}{$\begin{array}{l}\text { a. Predictors: (Constant), UMP_Juta, Pertumbuhan Ekonomi, } \\
\text { Inves_Triliun }\end{array}$} \\
\hline \multicolumn{8}{|c|}{ ANOVA $^{a}$} & \\
\hline \multicolumn{2}{|l|}{ Model } & \multicolumn{2}{|c|}{$\begin{array}{l}\text { Sum of } \\
\text { Squares }\end{array}$} & df & Mean Square & $\mathrm{F}$ & Sig. & \\
\hline \multirow[t]{3}{*}{1} & Regression & & 100 & 3 & \multirow{3}{*}{$\begin{array}{l}.033 \\
.001\end{array}$} & \multirow[t]{3}{*}{27.360} & \multirow[t]{3}{*}{$.002^{\mathrm{b}}$} & \\
\hline & Residual & & 006 & 5 & & & & \\
\hline & Total & & 106 & 8 & & & & \\
\hline \multirow{2}{*}{\multicolumn{9}{|c|}{$\begin{array}{l}\text { a. Dependent Variable: Bekerja_Juta } \\
\text { b. Predictors: (Constant), UMP_Juta, F }\end{array}$}} \\
\hline & & & & & & & & \\
\hline \multicolumn{9}{|c|}{ Coefficients $^{a}$} \\
\hline \multirow[b]{2}{*}{ Model } & & & \multicolumn{3}{|c|}{ Unstandardized Coefficients } & $\begin{array}{c}\text { Standardized } \\
\text { Coefficients }\end{array}$ & \multirow[b]{2}{*}{$\mathrm{t}$} & \multirow[b]{2}{*}{ Sig. } \\
\hline & & & & & Std. Error & Beta & & \\
\hline \multirow[t]{4}{*}{1} & (Constant) & & & 858 & .153 & & 12.131 & .000 \\
\hline & Pertumbuha & Ekonomi & & .014 & .024 & .071 & .580 & .587 \\
\hline & Inves_Triliur & & & 010 & .005 & .403 & 2.077 & .092 \\
\hline & UMP_Juta & & & .156 & .047 & .615 & 3.304 & .021 \\
\hline
\end{tabular}

Grafik 11. Hasil Estimasi Regresi Linier Berganda

Sumber: Hasil Penelitian 


\section{PENUTUP}

Demi mewujudkan visi misi menciptakan SDM yang unggul dan berdaya saing, pembangunan SDM di Provinsi Bali selayaknya dilakukan secara holistik dan terintegrasi. Daya saing SDM di Provinsi Bali seyogyanya terus ditingkatkan agar mampu memenuhi kompetensi dunia rill dewasa ini yang mensyaratkan kemampuan untuk cepat beradaptasi, berkolaborasi, dan berkreativitas sebagai bentuk profesionalisme. Harapannya, akan dihasilkan generasi pekerja keras yang dinamis, menguasai ilmu pengetahuan dan teknologi. Berbagai tantangan dan peluang yang mengiringi, perlu disikapi secara bijak dan tepat. Mengingat bahwa hingga saat ini sebagian besar penduduk yang bekerja memiliki tingkat pendidikan cukup rendah dan keterampilan terbatas untuk dapat memperoleh pekerjaan dengan gaji lebih tinggi.

Fokus penting dalam pembangunan SDM dapat dilakukan dengan beberapa langkah, antara lain mendorong kesempatan kerja yang berkualitas melalui peningkatan pertumbuhan ekonomi, perbaikan iklim investasi, peningkatan upah, mendorong kewirausahaan, dan menguatkan daya saing tenaga kerja lokal Bali. Melalui program kerja One Island One Management, diharapkan SDM Bali mampu unggul bersaing di kancah global dan menghadapi era industrialisasi 4.0.

\section{DAFTAR PUSTAKA}

BPS. 2015. Proyeksi Penduduk Bali 2010-2035. Bali: BPS Provinsi Bali.

BPS. 2019. BRS Ketenagakerjaan. Bali: BPS Provinsi Bali.

BPS. 2019. BRS IPM Tahun 2018. Bali: BPS Provinsi Bali.

Dewi, NLS dan I Ketut Sutrisna. 2014. Pengaruh Komponen Indeks Pembangunan Manusia terhadap Pertumbuhan Ekonomi Provinsi Bali. E-Jurnal Ekonomi Pembangunan Universitas Udayana Vol. 3 No. 3 [106-114].

Furqon, A.M. 2014. Analisis Pengaruh PDRB, Upah Minimum, Jumlah Unit Usaha, dan Investasi terhadap Penyerapan Tenaga Kerja pada Sektor Industri Manufaktur di Kabupaten Gresik Tahun 1998-2012. Malang: Universitas Brawijaya.

Kamar, K. 2017. Analisis Pengaruh Pertumbuhan Ekonomi dan Investasi terhadap Penyerapan Tenaga Kerja di Kabupaten Tangerang pada Tahun 2009-2015. Jurnal Bisnis \& Manajemen Vol. 17 No. 1, 1-10.

Tahir, K. 2018. Pengaruh Pertumbuhan Ekonomi, Investasi, Upah Minimum Provinsi terhadap Penyerapan Tenaga Kerja di Sulawesi Selatan. Jurnal Ekonomi Bisnis Syariah 1 (2), 110-132.

Wijaya, Andi, dkk. 2014. Analisis Faktor-faktor yang Mempengaruhi Penyerapan Tenaga Kerja di Provinsi Riau. Jom FEKON Vol. 1 No. 2. 